\title{
SACRU ȘI PROFAN ÎN ONOMASTICA PERSONAJElor lui Mircea Eliade
}

\author{
GHEORGHe GLODEANU \\ Centrul Universitar Nord Baia Mare, UTCN, România
}

\section{Sacred and profane in the names of Mircea Eliade's characters}

\begin{abstract}
Anthroponyms and toponyms play an essential role in Mircea Eliade's prose, contributing to the achievement of the fantastic effect. The names of places and characters are never chosen at random, as the text is always doubled by a much deeper subtext.
\end{abstract}

Keywords: sacred, profane, camouflage, fantastic, myth, rite, imaginary, mask, mystery, symbol, anthroponyms, toponyms, sacred geography.

Onomastica și toponimia joacă un rol esențial în proza lui Mircea Eliade, contribuind din plin la realizarea efectului fantastic. Numele locurilor și ale personajelor nu sunt alese niciodată la întâmplare, textul fiind dublat întotdeauna de un subtext mult mai profund. Autorul Nopții de Sânziene este creatorul unui univers imaginar propriu, bazat pe irecognoscibilitatea miracolului, pe camuflarea sacrului in profan. Scriitorul continuă fantasticul de tip metafizic impus la noi de către Mihai Eminescu, prin creaţii precum Sărmanul Dionis sau Avatarii faraonului Tla. Este vorba de o direcție pretențioasă, cultivată de către foarte puțini scriitori români. Spre deosebire de marele său predecesor, Eliade rămâne deschis și la numeroase alte surse de inspirație, precum credințele populare autohtone, universul mitologiei, problemele spectacolului sau filozofia indiană. Nu trebuie uitat faptul că și Mihai Eminescu are deja un text de valoare intitulat Moartea lui Ioan Vestimie, în care se zugrăvește ceea ce se întâmplă cu sufletul mortului în cele trei zile ce preced înmormântarea. Spre deosebire de predecesorii săi, Mircea Eliade nu este numai autorul unei proze fantastice de certă calitate, dar și creatorul unei teorii personale despre fantastic. Foarte puțini sunt scriitorii din literatura română care, pe lângă niște opere valoroase, au reușit performanța de a elabora și o personală poetică a fantasticului. I-am putea aminti pe V. Beneș, Al. Philippide, Oscar Lemnaru și Vintilă Horea, dar observațiile acestora sunt departe de profunzimea și originalitatea ideilor vehiculate de către Mircea Eliade. În viziunea istoricului religiilor, lumea este un camuflaj, o rețea de simboluri ce pot fi decodificate doar de către personajele inițiate. De altfel, în funcție de relația lor cu marile taine ale lumii, protagoniștii narațiunilor lui Mircea Eliade pot fi împărțiți în personaje inițiate, care au acces la tainele ultime (chiar dacă nu le dezvăluie) și în ignoranți, personaje mediocre puse față în față cu 
niște situații ce le depășesc capacitatea de înțelegere. Lucrurile nu sunt, însă, niciodată atât de simple, deoarece, adept al unei narațiuni labirintice, asemănătoare cu cea din prozele lui Jorge Luis Borges, personajele inițiate ale scriitorului suferă adesea de o misterioasă amnezie, ce marchează ruperea de origini, imposibilitatea comunicării cu sacrul. Nu întâmplător, personajelor li se fac mereu diferite semne, rolul lor fiind acela de a declanșa procesul anamnetic. În esență, în proza lui Mircea Eliade, manifestarea fantasticului echivalează cu iruperea sacrului în profan în modalitățile cele mai insolite. Aceasta deoarece lumea în care trăiește omul modern este o lume profund desacralizată, în care a fost deja proclamată „moartea lui Dumnezeu”. Desacralizarea a fost provocată de evoluția științelor exacte, în măsură să-l scoată pe om din orizontul misterului. Desacralizarea nu este totală, drept consecință sacrul se poate manifesta în cele mai neobișnuite locuri. Un exemplu elocvent este toposul degradat al țigăncilor, care ilustrează perfect teoria camuflării sacrului în profan. Mircea Eliade se dovedește un creator de mistere, un demiurg ludic în sfera imaginarului. Asemenea unui bun autor de romane polițiste, prozatorului îi place suspansul și știe să își deruteze cititorul propunându-i numeroase piste false. Din acest punct de vedere, narațiunea intitulată Nouăsprezece trandafiri se dovedește elocventă, transformându-se într-o ecuație cu numeroase necunoscute, ce amintește de întrebările Sfinxului mitologic. Iar cei care nu găsesc răspunsul potrivit se pierd în labirintul semnificațiilor. În sfera fantasticului, scriitorul nu dezvăluie niciodată realitățile ultime, preferând să recurgă la o abilă tehnică a sugestiei. Cum textul are întotdeauna un subtext, cititorul este obligat să se transforme într-un hermeneut pus să descifreze un mesaj ocult. Pornind de la decriptarea unor semne tainice, relatările propun întotdeauna mai multe soluții posibile, în măsură să îi deruteze pe cititori.

Personajele lui Mircea Eliade trăiesc într-o geografie simbolică, într-un topos cu puternice rezonanțe mitice. Pornind de la coordonatele Bucureștiului interbelic, scriitorul creează un spațiu imaginar propriu, în care sacrul este bine camuflat în profanul cenușiu și cotidian. Pentru cel obligat să trăiască în exil, orașul copilăriei se transformă într-un teritoriu fabulos, într-un topos cu puternice rezonanțe mitice, de care se simte legat în mod anteic. Orașul paradiziac al copilăriei lui Mircea Eliade nu este - în ciuda evidențelor de factură etimologică - „orașul lui Bucur”, numele lui venind mai degrabă de la „Helis”, adică „Cetatea Bucuriei”, urbea ridicată pe aceste meleaguri de către regele Dromihete. Nu întâmplător, narațiunea intitulată Pe strada Mântuleasa ne introduce în plin mister. Toponimia nu este întâmplătoare, ea sugerând posibilitatea salvării, a identificării sacrului camuflat în profan. Un personaj caracteristic pentru acest spațiu privilegiat este bătrânul învățător Zaharia Fărâmă, cel care cunoaște ca nimeni altul mitologia locului. Critica literară a atras atenția asupra semnificațiilor numelui Fărâmă. Este vorba aici nu numai de o parabolă a omului fragil, care reușește să se salveze din ghearele anchetatorilor săi prin intermediul povestirii, ci și de o tehnică narativă în care lucrurile sunt spuse în mod fragmentar, „pe fărâme”, tocmai pentru a deruta. Narațiunea ilustrează foarte bine dihotomia dintre două lumi, cea a mitului și a credințelor populare în care trăiesc bătrânul învățător și copiii de pe strada 
Mântuleasa și lumea pragmatică, desacralizată, a anchetatorilor. În ciuda faptului că i se cere să povestească niște lucruri concrete, bătrânul înțelept se refugiază în sfera mitului și vorbește despre niște întâmplări fabuloase. Pentru a fi bine înțeles, el are nevoie mereu de niște narațiuni ajutătoare, ceea ce face ca relatarea să dobândească o structură labirintică. Semnificativ se dovedește și prenumele personajului. Cuvântul Zaharia are origine ebraică, provenind din Zakaryah sau Zakarjah. Verbul zakar trimite la problemele memoriei și ale anamnezei, probleme esențiale în proza lui Mircea Eliade. Nu întâmplător, Zaharia Fărâmă este omul înzestrat cu o memorie fabuloasă, care, prin povestirile sale, încearcă să resacralizeze lumea, să o remitizeze. Verbul zakar semnifică „a-și aminti”, în timp ce particula jah trimite la Jahve, numele divinității. Foarte important este faptul că narațiunea este declanșată de o confuzie onomastică legată de unul din foștii elevi ai învățătorului. În locul lui Vasile Borza, institutorul de odinioară îl întâlnește pe Mihail Borza, personaj care trăiește sub regimul măștii, asumându-și o falsă identitate. Prenumele Vasile provine din grecescul basileus „rege”. Demersul inițiatului are drept consecință firească demascarea impostorului, a falsului rege, care se dovedește a fi un fost agent al Siguranței. Nu sunt întâmplătoare nici numele foștilor elevi ai școlii de pe strada Mântuleasa. Din rândul acestora se remarcă îndeosebi Lixandru, versiune prescurtată a celebrului antroponim Alexandru, care trimite la cuceririle extraordinare ale lui Alexandru cel Mare. În limba greacă, Alexandros înseamnă protector al oamenilor. Antroponimul este alcătuit din doi termeni: alexo „a apăra” și andros „bărbat, om”. Un personaj fabulos este gigantica Oana, cea care se trage dintr-un neam de uriași, trimițând la lumea miturilor. Oana din narațiunile labirintice ale lui Fărâmă este un personaj ce trimite la miturile antice. Numele ei se constituie o variantă a antroponimului Ioana. Provenind din ebraicul Yochanan, cuvântul are semnificația „Dumnezeu este milos”. Versiune feminină a macrantropului din povestirea Un om mare, personajul se roagă la lună, veritabilă întruchipare a fertilităţii. Tot de lumea fabuloasă a uriașilor ține și Doftorul, a cărui identitate adevărată se ascunde în spatele unui supranume.

În antiteză cu exponenții universului mitic, Mircea Eliade ne oferă și câteva personaje ce țin de lumea profană. Este vorba de anchetatorii care nu sunt interesați de mituri, ci de aflarea unei informații pragmatice: locul unde a fost ascuns tezaurul polonez. Criticii au remarcat faptul că teribila Anca Vogel își are originea în sinistra Ana Pauker, întruchipare a puterii absolute și a abuzurilor din anii totalitarismului. Acesteia i se adaugă nume precum Albini, Economu, Borza. Alteori, numele este substituit cu cifrele reflectând importanța individului într-o ierarhie a puterii totalitare: nr.1, nr.2 etc. În interiorul sistemului totalitar, poziția socială sau politică pe care o ocupi conferă greutate numelui.

Și narațiunea intitulată În curte la Dionis ne lasă să pătrundem pe teritoriul unui București cu puternice rezonanțe mitice. Orașul este imaginat ca o imensă grădină imagine paradiziacă prin excelență - dominată de Zeul Dionysos, ceea ce trimite la o veritabilă grădină a desfătărilor. Deja titlul narațiunii are puternice rezonanțe mitice. În plin război rece, scriitorul vorbește despre puterea artei de a salva lumea. De aici și 
reîntoarcerea periodică la mitul lui Orfeu și al Euridicei, al căror mesaj are o importantă funcție soteriologică. În narațiunea intitulată În curte la Dionis se petrece un lucru mai puțin obișnuit. Pe de o parte, personajele trăiesc sub regimul măștii, adevărata lor identitate rămânând camuflată. Orfeu este Adrian, iar Euridice se numește Leana. Pe de altă parte - după cum lucrurile au fost surprinse de către exegeți - asistăm la un mit răsturnat, tot așa cum narațiunea Domnişoara Christina ne propune un Luceafăr întors. De aici o insolită inversiunea a rolurilor. Cum Adrian-Orfeu suferă un accident, el este cuprins de o misterioasă amnezie, ceea ce îl face să își uite adevărata menire, mesajul pe care trebuie să îl transmită oamenilor prin intermediul artei. Numele nu este ales la întâmplare, deoarece Sfântul Adrian a fost considerat patronul mesagerilor. De data aceasta avem de-a face, însă, cu tema salvatorului salvat. Nu Orfeu este cel care încearcă să o salveze pe Euridice din Infern, ci invers. Confruntată cu misterioasa amnezie a lui Adrian, Leana (versiune prescurtată a Ilenei, antroponim ce apare frecvent în basmele noastre populare) este cea care își asumă rolul mesagerului. În acest sens, cântecele prin intermediul cărora reușește să își vrăjească auditoriul devin niște vehicule ale mesajului mitic. Dar ele alcătuiesc și niște semne a căror menire este declanșarea procesului anamnetic. Leana mai este supranumită și Văduva, deoarece și-a pierdut perechea, pe care caută să o regăsească cu disperare.

Semnificativă se dovedește și toponimia din curtea zeului Dionysos. De geografia mitică a Bucureștiului țin cârciumile cu nume simbolice, în care poate fi văzută acest Orfeu feminin care este Leana. Cea mai importantă este Floarea-soarelui, numele grădinii găsindu-se în consonanță cu numele străzii pe care se situează, strada Popa Soare. Nu întâmplător, evenimentele se derulează pe două planuri paralele care, la un moment dat se intersectează prin regăsirea simbolică a protagoniștilor. Fiecare plan are în centru câte un personaj simbolic, a cărui existență se derulează sub regimul măștii și care devine un purtător al misterului. Adrian și-a pierdut memoria, nu își cunoaște adevărata identitate, dar știe că are o întâlnire importantă la ora 4,30. În loc să o regăsească pe Leana, mesagerul sacrului se întâlnește cu Orlando, exponentul lumii profane. Asemenea anchetatorilor din nuvela Pe strada Mântuleasa, personajul este un exponent al puterii. În acest sens, supranumele Il Comandante reflectă din plin acest lucru. Spirit pragmatic și rațional, Orlando reprezintă o variantă demitizată a celebrului Roland. Confuziile sunt provocate de coincidența contrariilor, adică de întâlnirea temporară a sacrului cu profanul. Atât întâlnirea importantă la care vrea să ajungă Orfeul amnezic, cât și reuniunea organizației patronate de către raționalul Orlando sunt programate la aceeași oră. În ciuda numeroaselor încurcături, cele două fire narative se dovedesc convergente, Orfeul amnezic fiind salvat de către perechea lui, Euridice. Tot în final este prezentat și mesajul camuflat al cântecului În curte la Dionis, care conferă și titlul relatării. Este vorba de o creație elaborată sub semnul lui Orfeu, care anticipează „beatitudinea fără nume” din curtea zeului Dionysos. Mesajul transmis de către celebrul cântăreț este acela că poezia este nu numai o soteriologie, ci și o tehnică politică. Doar ea este în măsură să schimbe omul societăților desacralizate, să îl mântuie. Schimbarea nu trebuie să înceapă de la elite, ci de la oamenii simpli, care își petrec noaptea prin grădinile de vară și restaurante. 
Într-o geografie mitologică a Bucureștiului trăiește și Gavrilescu, profesorul de pian. Acesta reprezintă o variantă degradată a lui Orfeu, deoarece are un destin modificat. La fel ca și în cazul lui Ștefan Viziru, protagonistul romanului Noaptea de Sânziene, drama personajului se datorează faptului că s-a căsătorit cu cineva care nu i-a fost menit. De altfel, personajul însuşi recunoaște că a fost pedepsit pentru păcatele sale, decăzând de la condiția de artist la cea de modest profesor de pian, care se întreține dând lecții particulare. Locvacitatea personajului se explică prin nevoia de a-și justifica degradarea, destinul modificat. Numele lui Gavrilescu reprezintă o variantă degradată a arhanghelului Gabriel (Gavril), purtătorul mesajului divin. De aici rolul sufixului -escu de la sfârșitul numelui. În anii formării sale, o iubește pe nemțoaica Hildegard, femeia visurilor sale, dar, la fel ca în opera lui Caragiale, căldura mare dereglează reacțiile firești ale personajului. Nu este întâmplătoare nici trimiterea la experiența trăită de către colonelul Lawrence, lovit în moalele capului de soarele pătrunzător al deșertului. Experiența acestuia anticipează povestea vieții modificate arbitrar a lui Gavrilescu. Numele Hildegard este de origine germană, fiind alcătuit din hild „luptă” și gard „încercuire". Sub imperiul soarelui dogoritor de vară, Gavrilescu o cunoaște pe Elsa, întâlnire ce îi va modifica în mod radical destinul. Numele Elsa constituie o variantă prescurtată a Elisabetei și, în aparență, purtătoarea numelui biblic pare a fi purtătoarea mesajului divin. În realitate, Elsa se va dovedi doar o variantă domestică, degradată a consoartei, a idealului feminin.

Insolitul narațiunii constă în faptul că schimbările radicale din destinul profesorului de pian sunt provocate de două accidente: căldura mare şi uitarea partiturilor. La fel ca în tinerețe, căldura excesivă este cea care dereglează reacțiile firești ale personajului. Toponimia joacă și ea un rol important în circumscrierea unui spațiu cu puternice rezonanțe mitice. Pentru a amplifica dimensiunile simbolice ale relatării, Mircea Eliade trimite frecvent și la numerologie. Gavrilescu iș̦i uită partiturile pe Strada Preoteselor la numărul 18 (compus din 6X3), număr la care locuiește doamna Voitinovici și nepoata ei, Otilia Pandele. Importante se dovedesc și vehiculele mitice prezente în narațiune: tramvaiul și birja. Ele îl transportă pe Gavrilescu în topografia Bucureștiului mitic dinspre sacru înspre profan și dinspre lumea celor vii înspre lumea celor morți. Nu întâmplător, părăsind strada Preoteselor, Gavrilescu urcă în tramvaiul care îl duce la Vama Poștei, topos cu rezonanțe mitice, ce marchează trecerea de la profan înspre sacru, către lumea de dincolo. Aici, la numărul 101, se găsește domiciliul lui Gavrilescu și al Elsei.

Deși este considerat un teritoriu rău famat de către trecători, grădina răcoroasă, plină de nuci și de tei a țigăncilor, constituie o tentație puternică în geografia Bucureștiului cuprins de zăpușeală. În ciuda aparențelor degradante, ea reprezintă întruchiparea unui spațiu paradiziac, o manifestare a sacrului camuflat în profan. Am putea spune că grădina țigăncilor constituie o nouă grădină a desfătărilor, o nouă întruchipare a curții lui Dionis. Fapt important, pătrunderea în grădina țigăncilor produce declanșarea procesului anamnetic, prin intermediul căruia personajul își redobândește adevărata identitate. Dintr-o dată, Gavrilescu își aduce aminte de marile drame ce i-au marcat existența: iubirea pentru Hildegard și vocația de artist, ratată din 
cauza opțiunilor sale greșite. În spațiul sacru de la țigănci, Gavrilescu o va reîntâlni pe Hildegard, destinul lor - ratat în plan profan - împlinindu-se în moarte.

În mod paradoxal, nuvela are și o serie de personaje care nu poartă nume, dar în spatele cărora se pot ghici cu ușurință o serie de identităţi mitice. Este vorba de grupul celor trei fete (țiganca, grecoaica și evreica) dintre care Gavrilescu trebuie să ghicească țiganca. Ele au fost considerate de către criticii literari niște întruchipări ale miticelor Parce. Baba care îl primește pe profesorul de pian la intrarea în grădina țigăncilor pare a fi o versiune a Cerberului, dar un cerber domesticit. În sfârșit, vizitiul care îi poartă pe Gavrilescu și pe Hildegard înspre lumea de dincolo este o întruchipare a miticului luntraș Charon, iar birja lui este un vehicul mitic. Finalul acesta seamănă foarte mult cu cel al romanului Noaptea de Sânziene, demonstrând faptul că adevărata iubire nu se împlinește pe pământ, adevărata iubire se împlinește doar în cer. Mircea Eliade reușește să creeze în mijlocului Bucureștiului profan un spațiu imaginar propriu, cu numeroase rezonanțe simbolice.

Alături de numeroase alte procedee, onomastica și toponimia joacă un rol important în proza fantastică a lui Mircea Eliade, contribuind din plin la circumscrierea unor spații imaginare, a unor universuri paralele, a sacrului camuflat în profan.

\section{Bibliografie selectivă}

Borș, M.. 2015. Mitologii nominale în proza lui Mircea Eliade. Iași: Editura Institutul European.

Călinescu, M.. 2002. Despre Ioan P.Culianu şi Mircea Eliade. Amintiri, lecturi, reflecții. Iași: Editura Polirom.

Culianu, I. P. 1995. Mircea Eliade, ediţie revăzută şi augmentată. București: Editura Nemira.

Eliade, M. 1990. Incercarea labirintului. Convorbiri cu Claude-Henri Rocquet. Cluj-Napoca: Editura Dacia.

Eliade, M. 1997 (1991). Memorii (1907-1960), vol. I-II. Bucureşti: Editura Humanitas.

Eliade, M. 1993. Jurnal, volumul I (1941-1969), vol. II (1970-1985). București: Editura Humanitas.

Eliade, M. 1994. Integrala prozei fantastice, vol. I-III. Iași: Editura Moldova.

Eliade, M. 1992. Sacrul şi profanul. București: Editura Humanitas.

Eliade, M. 1994. Imagini şi simboluri. Eseu despre simbolismul magico-religios. București: Editura Humanitas.

Eliade, M. 1995. De la Zalmoxis la Genghis-Han. Studii comparative despre religiile Daciei şi Europei Orientale. București: Editura Humanitas.

Evseev, I. 1997. Dicționar de magie, demonologie şi mitologie românească. Timișoara: Editura Amarcord.

Glodeanu, G. 2009. Coordonate ale imaginarului în opera lui Mircea Eliade. Iași: Editura Tipo Moldova.

Iordan, I. 1983. Dicționar al numelor de familie românești. București: Editura Științifică și Enciclopedică.

Pătruț, I. 1980. Onomastica românească. București: Editura Științifică și Enciclopedică.

Petrache, T. 1998. Dicționar enciclopedic al numelor de botez. București: Editura Anastasia.

Ruşti, D. 1998. Dicționar de simboluri din opera lui Mircea Eliade. București: Editura Coresi. 